\title{
EFEKTIFTAS MENGUNYAH BUAH BERSERAT DAN BERAIR TERHADAP KUANTITAS BAKTERI STREPTOCOCCUS MUTANS PADA ANAK KEBUTUHAN KHUSUS
}

\author{
Tri Wiyatini $^{\bowtie 1}{ }^{1}$, Endah Aryati Ekoningtyas ${ }^{2}$, Prasko $^{3}$
}

\begin{abstract}
ABSTRAK
Anak yang menderita retardasi mental berkaitan dengan koordinasi otot yang mengakibatkan keterlambatan perkembangan gerakan (motorik), bicara, dan keterbatasan menyesuaikan diri dengan lingkungan. Kelainan ini juga di tambah dengan kesulitan anak untuk dapat menjaga kesehatan gigi dan mulutnya secara mandiri dan kurang aktifnya otot mulut untuk mendapatkan pembersihan alamiah yang baik. Proses mengunyah makanan berserat ini akan merangsang dan meningkatkan produksi air liur (saliva). Buah apel merupakan salah satu buah-buahan berserat yang dapat diperoleh di pasaran. Dan buah apel memiliki kemampuan self cleansing effect. Penelitian ini bertujuan untuk mengetahui pengaruh mengunyah buah apel terhadap kuantitas bakteri streptococcus mutans pada anak berkebutuhan khusus.

Jenis penelitian yang digunakan adalah deskriptif. Metode yang digunakan dalam penelitian ini adalah quasi experimen dan rancangan penelitian dilakukan dengan one group pretest dan postest. Dalam penelitian ini sampel dilakukan perhitungan jumlah bakteri sebelum dan setelah mengunyah buah apel pada saliva dengan menggunakan metode Total Plate Count. Sampel adalah 15 siswa SD kelas I-VI sub bagian tuna grahita ringan di SLB Yayasan Widya Bhakti Semarang berjumlah 40 siswa.

Hasil penelitian menunjukkan uji paired t-test menunjukkan bahwa terdapat efektifitas mengunyah buah berserat dan berair terhadap kuantitas bakteri streptococcus mutans pada anak kebutuhan khusus, dan dari analisa data menunjukkan perbedaan yang signifikan dengan nilai t hitung sebesar 3.778 df (derajat kebebasan) dan $p$ value $=0,002(p<0,05)$.
\end{abstract}

Kata kunci : Buah berserat dan berair, kuantitas bakteri streptococcus mutans

\begin{abstract}
Children who suffer from mental retardation associated with muscle coordination resulted in delays on the development of movement (motoric), speech, and limitations adjust to the environment. The disorder is also added to the difficulties of children to be able to maintain healthy teeth and mouth independently and are less active mouth muscles to get a good natural cleansing. The process of chewing fibrous foods will stimulate and increase saliva production. The apple is a fibrousfruit which can be obtained on the market. And apple has the ability to self-cleansing effect. This study aims to determine the effect of chewing an apple to the quantity of Streptococcus mutans bacteria in children with special needs

This type of research is descriptive. The method used in this study is a quasi experimental and design studies carried out by one group pretest and posttest. In this study, a sample calculation of the number of bacteria before and after chewing apples in saliva using Total Plate Count. Samples were 15 students from elementary classes I-VI mild mental retardation in special schools amounted foundation Widya Bhakti Semarang.

The results showed statisticfrom paired t-test that there are effective chew of fibrousand juicy fruit on the quantity of bacteria Streptococcus mutans in a special needs child, and from the analysis of the data showed a significant difference with the $t$ value of $3,778 d f$ (degrees of freedom) and $p$ value $=0.002(p<0.05)$.
\end{abstract}

Keywords : fruit fibrous watery, streptococcus mutans quantity

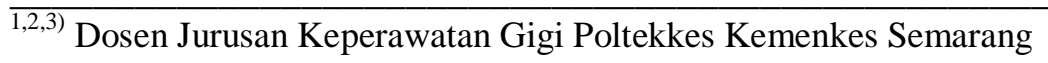

$凶$ : triwiyatini@gmail.com
} 


\section{PENDAHULUAN}

Retardasi mental atau keterbelakangan mental adalah suatu keadaan ketidaksempurnaan perkembangan kemampuan mental yang mengakibatkan keterlambatan perkembangan gerakan (motorik), bicara, dan keterbatasan menyesuaikan diri dengan lingkungan. Kelainan ini juga di tambah dengan kesulitan anak untuk dapat menjaga kesehatan gigi dan mulutnya secara mandiri dan kurang aktifnya otot mulut untuk mendapatkan pembersihan alamiah yang baik (Maulani, 2005). Anak yang menderita retardasi mental berkaitan dengan koordinasi otot mulut yang tidak baik menyebabkan refleks menelan yang seharusnya otomatis teratur menjadi terganggu sehingga menyebabkan produksi air liurnya menjadi berlebihan.

Karies merupakan suatu penyakit jaringan keras gigi, yaitu email, dentin dan sementum, yang di sebabkan oleh aktivitas jasad renik dalam suatu karbohidrat yang dapat di ragikan (Nugraha, 2008). Sampai sekarang, karies merupakan masalah kesehatan gigi dan mulut yang masih memerlukan perhatian serius. prevalensi penyakit gigi ini dilaporkan di Indonesia masih cukup tinggi. Pada umumnya pasien dengan retardasi mental memiliki kesehatan rongga mulut dan oral hygiene yang lebih rendah dibanding dengan orang-orang yang tanpa cacat perkembangan. Data menunjukkan bahwa pasien dengan retardasi mental memiliki karies yang lebih banyak dan prevalensi gingivitis yang lebih tinggi serta penyakit-penyakit periodontal lainnya dibanding dengan masyarakat umum (Salmiah, 2010). Menurut Simanjuntak (2009), setiap kali seseorang mengkonsumsi makanan dan minuman yang mengandung karbohidrat maka beberapa bakteri penyebab karies dirongga mulut akan memulai memproduksi asam sehingga terjadi demineralisasi yang berlangsung selama 2030 menit setelah makan. Diantara periode makan, saliva akan bekerja menetralisir asam dan membantu proses remineralisasi.
Streptococcus mutans merupakan kuman yang kariogenik karena mampu segera membuat asam dari karbohidrat yang di ragikan (Kidd dan Bechal, 1991). Streptococcus mutans merupakan bakteri gram positif, bersifat nonmotil (tidak bergerak), bakteri anaerob fakultatif. Memiliki bentuk kokus yang sendirian berbentuk bulat atau bulat telur dan tersusun dalam rantai. Bakteri ini tumbuh secara optimal pada suhu sekitar 180-400 Celsius (Nugraha, 2008).

Sayuran dan buah yang berserat serta mengandung air bersifat membersihkan karena harus di kunyah dan dapat merangsang sekresi saliva karenanya dapat berperan sebagai penghambat terjadinya karies. Proses mengunyah makanan berserat ini akan merangsang dan meningkatkan produksi air liur (saliva). Buah apel merupakan salah satu buah-buahan berserat yang dapat diperoleh di pasaran. Dan buah apel memiliki kemampuan self cleansing effect. Buah apel segar banyak mengandung vitamin, mineral, serabut-serabut kasar, kadar air, dan tanin (Soelarso, 1997). Zat inilah yang membantu membersihkan gigi dari sisa makanan yang menempel pada gigi (Ircham M, Asmar Y, 2005).

Apel banyak disukai karena rasanya khas dan manis. Dibalik bentuknya yang menggoda, ternyata buah apel mempunyai banyak khasiat. Buah apel yang sangat populer di masyarakat, memiliki nama latin Pyrus malus, merupakan buah yang kaya akan zat fitokemikal yang bermacam-macam manfaat apel bagi kesehatan manusia berhubungan dengan banyaknya polyphenol atau fitokemikal yang terkandung di dalamnya yang salah satunya adalah flavonoid. Flavonoid yang paling penting yang terdapat pada apel adalah flavanol atau catechin atau disebut juga flavan-3-ols, flavonol dan anthocyanin. Terdapat penelitian yang menyebutkan bahwa catechin teh memiliki aktivitas antibakterial dan bakteri gram positif lebih sensitif terhadap catechin tersebut bila dibandingkan dengan bakteri gram negatif (Khairan, 2007). Buah 
apel juga memiliki kandungan tanin. Tanin adalah zat yang berfungsi membersihkan dan menyegarkan mulut, sehingga dapat mencegah kerusakan gigi dan penyakit gusi. Penelitian ini bertujuan untuk mengetahui pengaruh mengunyah buah apel terhadap kuantitas bakteri streptococcus mutans pada anak SLB.

\section{METODE PENELITIAN}

Jenis penelitian yang digunakan adalah deskriptif. Data hasil penelitian menggunakan data kuantitatif yaitu data yang berhubungan dengan angka-angka, baik yang di peroleh dari hasil pengukuran, maupun dari nilai suatu data yang di peroleh dengan jalan mengubah data kualitatif ke dalam data kuantitatif (Notoatmodjo, 2005).

Metode yang digunakan dalam penelitian ini adalah quasi experimen dan rancangan penelitian dilakukan dengan one group pretest dan postest. Dalam penelitian ini sampel dilakukan perhitungan jumlah bakteri sebelum dan setelah mengunyah buah apel pada saliva dengan menggunakan metode Total Plate Count.

Rancangan yang akan dilakukan dapat digambarkan sebagai berikut :

\begin{tabular}{|ccc|}
\multicolumn{1}{c}{ Pretest } & perlakuan & postes \\
\hline 01 & $\mathrm{X}$ & 02 \\
\hline
\end{tabular}

Keterangan :

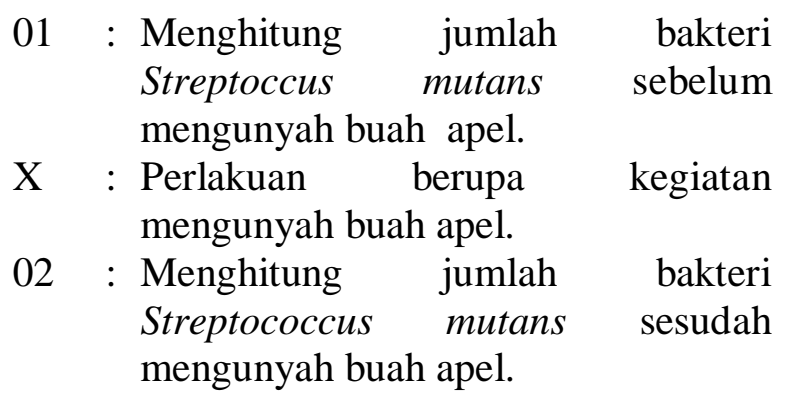

Populasi dalam penelitian ini adalah siswa SD kelas I-VI sub bagian tunagrahita ringan di SLB Yayasan Widya Bhakti Semarang yang berjumlah 40 siswa. Teknik pengambilan sampel menggunakan total sampling. Sampel pada penelitian ini berjumlah 15 siswa. Yaitu siswa kelas III berjumlah 5 siswa, siswa kelas IV yang berjumlah 4 siswa, kelas $\mathrm{V}$ yang berjumlah 6 siswa pada sub bagian tunagrahita ringan di SLB Yayasan Widya Bhakti Semarang. Pengukuran Jumlah bakteri Streptococcus Mutans/ml sampel pada masing-masing pot sputum yang berisi saliva sebelum dan sesudah mengunyah buah apel dilakukan di Laboratorium gizi, Poltekkes Kemenkes Semarang.

Pelaksanaan dilakukan dengan cara sampel meludah di pot sputum yang telah di sediakan kemudian mengunyah buah apel sebanyak 50 gr buah apel selama 2 menit setelah itu meludah lagi. Kemudian dilakukan perhitungan jumlah koloni bakteri dengan metode TPC (Total Plate Count) dari saliva tersebut.

Data hasil penelitian disajikan secara analitik deskriptif kuantitatif yaitu mendeskripsikan hasil penelitian ke dalam tabel. Adapun untuk mengetahui pengaruh mengunyah buah apel terhadapa jumlah bakteri streptococcus mutans, menggunakan uji paired t-test dengan $\alpha 0,05$.

\section{HASIL DAN PEMBAHASAN}

Seluruh responden mendapat tahapan perlakuan dengan tahapan prosedur yang sama. Adapun hasil data sebagai berikut :

\section{Hasil Deskriptif}

Untuk mengetahui Nilai bakteri Streptococcus mutans pada anak SLB Yayasan Widya Bhakti Semarang sub bagian Tunagrahita Ringan sebelum dan setelah mendapat perlakuan adalah sebagai berikut : 
Tabel 1. Distribusi jumlah bakteri streptococcus mutans sebelum dan sesudah mengunyah buah apel pada anak SLB Yayasan Widya Bhakti

Semarang sub bagian Tunagrahita Ringan

\begin{tabular}{|c|c|c|c|c|}
\hline \multirow[t]{2}{*}{ No } & \multirow[t]{2}{*}{$\begin{array}{c}\text { Nama } \\
\text { sampel }\end{array}$} & \multicolumn{2}{|c|}{$\begin{array}{c}\text { Jumlah bakteri } \\
\text { Streptococcus Mutans } \\
\text { /ml sampel }\end{array}$} & \multirow[t]{2}{*}{$\begin{array}{l}\text { Selisih } \\
\text { Jumlah } \\
\text { Bakteri }\end{array}$} \\
\hline & & Sebelum & Sesudah & \\
\hline 1 & A & $4,5 \times 10^{5}$ & $1,5 \times 10^{5}$ & $3,0 \times 10^{5}$ \\
\hline 2 & B & $3,6 \times 10^{5}$ & $2,1 \times 10^{5}$ & $1,5 \times 10^{5}$ \\
\hline 3 & $\mathrm{C}$ & $8,0 \times 10^{5}$ & $1,5 \times 10^{5}$ & $6,5 \times 10^{5}$ \\
\hline 4 & D & $5,0 \times 10^{6}$ & $1,4 \times 10^{6}$ & $3,6 \times 10^{6}$ \\
\hline 5 & $\mathrm{E}$ & $4,0 \times 10^{6}$ & $2,2 \times 10^{6}$ & $1,8 \times 10^{6}$ \\
\hline 6 & F & $3,3 \times 10^{6}$ & $8,0 \times 10^{5}$ & $2,5 \times 10^{6}$ \\
\hline 7 & G & $6,0 \times 10^{6}$ & $1,0 \times 10^{6}$ & $5,0 \times 10^{6}$ \\
\hline 8 & $\mathrm{H}$ & $3,3 \times 10^{5}$ & $1,4 \times 10^{5}$ & $1,9 \times 10^{5}$ \\
\hline 9 & I & $3,0 \times 10^{5}$ & $2,2 \times 10^{5}$ & $8,0 \times 10^{4}$ \\
\hline 10 & $\mathrm{~J}$ & $6,5 \times 10^{6}$ & $1,0 \times 10^{6}$ & $5,5 \times 10^{6}$ \\
\hline 11 & $\mathrm{~K}$ & $5,6 \times 10^{5}$ & $3,6 \times 10^{5}$ & $2,0 \times 10^{5}$ \\
\hline 12 & $\mathrm{~L}$ & $1,4 \times 10^{6}$ & $3,2 \times 10^{5}$ & $1,1 \times 10^{6}$ \\
\hline 13 & M & $2,6 \times 10^{6}$ & $2,3 \times 10^{5}$ & $2,4 \times 10^{6}$ \\
\hline 14 & $\mathrm{~N}$ & $3,4 \times 10^{6}$ & $1,7 \times 10^{6}$ & $1,7 \times 10^{6}$ \\
\hline \multirow[t]{2}{*}{15} & $\mathrm{O}$ & $1,8 \times 10^{6}$ & $1,0 \times 10^{6}$ & $8,0 \times 10^{5}$ \\
\hline & $\Sigma($ mean $)$ & $2,5 \times 10^{6}$ & $7,3 \times 10^{5}$ & $1,7 \times 10^{6}$ \\
\hline
\end{tabular}

Dari Tabel 1 diatas dapat di lihat bahwa terdapat perbedaan jumlah bakteri Streptococcus mutans $/ \mathrm{ml}$ sampel pada sampel 1-15 sebelum dan sesudah mengunyah buah apel.

Tabel 2. Prosentase perbedaan jumlah Bakteri Streptococcus Mutans Sebelum dan sesudah mengunyah buah apel pada anak SLB Yayasan

Widya Bhakti Semarang sub bagian Tunagrahita Ringan

\begin{tabular}{|c|c|c|c|c|c|c|}
\hline Metode & $\mathrm{N}$ & $\begin{array}{c}\text { Rata-rata } \\
\text { Jumlah } \\
\text { Bakteri } \\
\text { Streptococcus } \\
\text { Mutans } \\
\end{array}$ & $\begin{array}{c}\text { Prosentase } \\
\text { rata-rata } \\
\text { jumlah } \\
\text { bakteri }\end{array}$ & $\begin{array}{c}\text { Rata-rata } \\
\text { Perbedaan } \\
\text { (selisih) } \\
\text { jumlah } \\
\text { bakteri } \\
\end{array}$ & $\begin{array}{c}\text { Prosentase } \\
\text { perbedaan } \\
\text { (selisih) } \\
\text { jumlah } \\
\text { bakteri } \\
\end{array}$ & $\mathrm{P}$ \\
\hline $\begin{array}{c}\text { Sebelum } \\
\text { mengunyah } \\
\text { buah apel }\end{array}$ & 15 & $2,5 \times 10^{6}$ & $77 \%$ & \multirow{2}{*}{$1,7 \times 10^{6}$} & \multirow{2}{*}{$54 \%$} & \multirow{2}{*}{0,002} \\
\hline $\begin{array}{c}\text { Sesudah } \\
\text { mengunyah } \\
\text { buah apel }\end{array}$ & 15 & $7,3 \times 10^{5}$ & $23 \%$ & & & \\
\hline
\end{tabular}

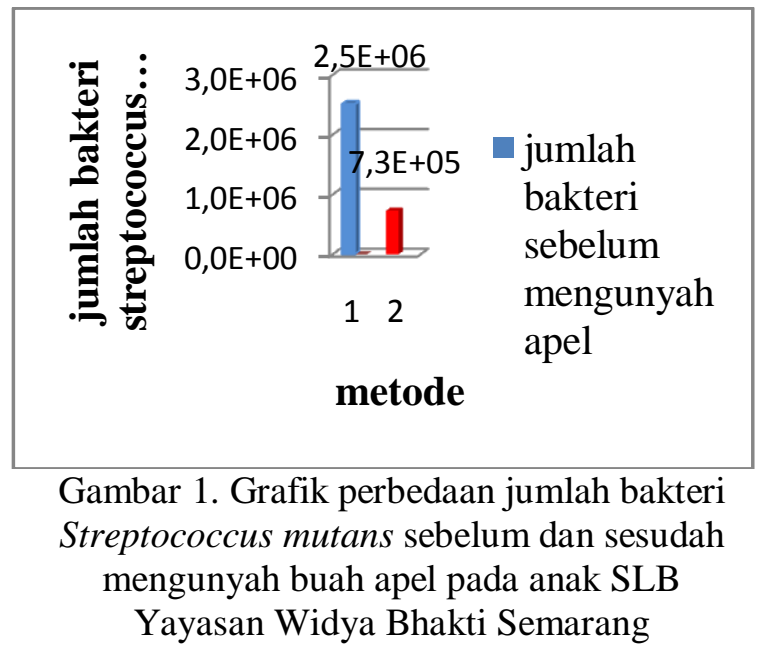

Pada Tabel 2 dan Gambar 1 diatas dapat dilihat bahwa perbedaan (selisih) jumlah bakteri sebelum dan sesudah mengunyah apel adalah $1,7 \times 10^{6}$ bakteri.

Untuk mengetahui pengaruh buah apel terhadap perbedaan jumlah bakteri Streptococcus mutans dilakukan uji statistik paired t-test dengan $\alpha 0,05$ didapat sebagai berikut :

Tabel 3. Hasil Uji Statistik Paired t-test perbedaan Bakteri Streptococcus mutans Sebelum dan Sesudah mengunyah Buah Apel pada Anak SLB Yayasan Widya Bhakti Semarang

T df sig. (2-tailed)

\begin{tabular}{llll}
\hline $\begin{array}{l}\text { pair 1 sebelum } \\
\text { mengunyah buah } \\
\text { apel-sesudah }\end{array}$ & 3.778 & 14 & .002 \\
mengunyah buah apel & & & \\
\hline
\end{tabular}

Dari Tabel 3 diatas dapat di lihat bahwa dari uji statistik paired t-test diperoleh nilai $\mathrm{t}$ hitung sebesar $3.778 \mathrm{df}$ (derajat kebebasan) sebesar 14 dan $\mathrm{p}$ value $=0,002$ $(\mathrm{P}<0,05)$.

Hasil Uji statistic uji paired t-test menunjukkan bahwa terdapat perbedaan yang signifikan dengan nilai t hitung sebesar 3.778 df (derajat kebebasan) dan $\mathrm{p}$ value $=0,002(\mathrm{P}<0,05)$. 


\section{PEMBAHASAN}

Proses mengunyah buah-buahan berserat akan merangsang dan meningkatkan produksi air liur (saliva). Proses mengunyah tersebut secara perlahan akan mengurangi pembentukan plak dan karies (Prawira, 2011). Kecuali tersebut kegiatan mengunyah dapat merangsang kerja otot dan hal ini dapat mempengaruhi produksi saliva dan kecepatan aliran saliva (Edwina A.M, Sally Joyston, 1991). Menurut penelitian Bintang Bestari (2005), kandungan serat dan asam dari apel dapat merangsang kecepatan sekresi saliva yang dapat menurunkan akumulasi plak.

Dari hasil analisa deskriptif terhadap jumlah bakteri Streptococcus mutans yang diteliti dengan perlakuan sebelum mengunyah apel dan sesudah mengunyah apel menunjukkan kegiatan mengunyah buah apel yang mana buah apel mengandung tanin dan flavanoid memiliki kemampuan untuk menurunkan jumlah bakteri Streptococcus mutans. Hal ini terlihat dari hasil perhitungan jumlah bakteri Streptococcus mutans sebelum dan sesudah mengunyah buah apel terhadap 15 sampel yang di teliti rata-rata jumlah bakteri Streptococcus mutans mengalami penurunan setelah diinkubasi selama 24 jam.

Adapun dari hasil uji statistik dengan paired t-test diperoleh nilai $\mathrm{P}=0,002$ ( $\mathrm{P}<$ $0,05)$ menunjukkan terdapat perbedaan yang bermakna terhadap jumlah bakteri Streptococcus mutans sebelum dan sesudah mengunyah apel. Flavonoid yang terdapat pada apel adalah flavanol atau catechin atau disebut juga flavan-3-ols, flavonol dan anthocyanin. Terdapat penelitian yang menyebutkan bahwa catechin teh memiliki aktivitas antibakterial dan bakteri gram positif lebih sensitif terhadap catechin tersebut bila dibandingkan dengan bakteri gram negatif. Buah apel juga memiliki kandungan tanin. Tanin adalah zat yang berfungsi membersihkan dan menyegarkan mulut, sehingga dapat mencegah kerusakan gigi dan penyakit gusi. Penyakit gusi disebabkan karena menempelnya bakteri pembentuk plak. Mekanisme penurunan jumlah bakteri Streptococcus mutans oleh buah apel dikarenakan adanya proses mengunyah buah apel. Proses mengunyah tersebut secara perlahan akan mengurangi pembentukan plak dan karies. Buah apel memiliki kandungan tanin, yang berfungsi membersihkan dan menyegarkan mulut, sehingga dapat mencegah kerusakan gigi dan penyakit gusi yang disebabkan karena menempelnya bakteri pembentuk plak. Kegiatan mengunyah memberikan efek positif yang berpengaruh menurunkan jumlah bakteri dan menyehatkan mulut.

\section{KESIMPULAN}

Berdasarkan hasil penelitian pada anak SLB Yayasan Widya Bhakti Semarang dapat di ambil kesimpulan bahwa ada penurunan Jumlah bakteri Streptococcus mutans sebelum mengunyah buah apel dan sesudah mengunyah buah apel dengan selisih mencapai $54 \%$ yaitu $1,7 \times 10^{6}$. Serta hasil penelitian menunjukkan terdapat perbedaan yang bermakna antara jumlah bakteri Streptococcus mutans sebelum dan sesudah mengunyah buah apel dengan hasil uji statistik paired t-test di peroleh nilai $\mathrm{P}$ value $=0,002$ karena $\mathrm{P}<0,05$.

\section{DAFTAR PUSTAKA}

Bintang Bestari, 2005, Pengaruh Mengunyah Buah Apel Terhadap pH Saliva, Surakarta: Fakultas Kedokteran Universtas Negeri Sebelas Maret

Edwina A. M. kidd dan Sally Joyston, 1991, Dasar-Dasar Karies Penyakit Dan Penanggulangannya, hal : 70, Terjemahan oleh Narlan Sumawinata dan Safrida Faruk, Jakarta : EGC 
Ircham, 1995, Menjaga Kesehatan Gigi dan Mulut, hal : 90, Liberty : Yogyakarta.

Kidd, E.A.M., dan Bechal, S.J., 1991, Dasar - Dasar Karies Penyakit dan Penanggulangannya, EGC : Jakarta.

Maulani, Chaerita, 2005, Kiat Merawat Gigi Anak, PT Elex Media Komputindo: Jakarta.

Notoadmodjo, Soekidjo, 2005, Metodologi Penelitian Kesehatan, PT Rineka Cipta : Jakarta.

Nugraha, A.W., 2008, Si Plak Dimanamana,

http://mikrobia.files.wordpress.com/2 008/05/streptococcus-mutans_31.pdf.

Prawira, Albert, 2010, Kondisi Oral Higiene dan Karies gigi pada Vegetarian dan non Vegetarian di Maha Vihara Maitreya Medan, http://repository.usu.ac.id/bitstream/1 23456789/22426/4/Chapter\%20II.pdf

Salmiah, Siti, 2010 Retardasi mental, http://repository.usu.ac.id/bitstream/1 23456789/1182/1/10E00506.pdf

Soelarso, 1997, Budi Daya Apel, hal : 14, Yogyakarta : Kanisius 